\title{
Deepwater Fisheries and Aspects of Their Impact on Seamount Habitat in New Zealand
}

\author{
Malcolm Clark and Richard O'Driscoll \\ National Institute of Water and Atmospheric Research \\ P. O. Box 14-901, Wellington, New Zealand
}

\begin{abstract}
Deepwater fisheries for orange roughy (Hoplostethus atlanticus) and oreos (Pseudocyttus maculatus) in New Zealand waters have been established for 20-30 years. Over time the fisheries have become more focused on seamounts, where aggregations of the fish can occur for spawning or feeding. The catch of orange roughy in particular from these features has increased from about $30 \%$ of the total catch in 1985 to $80 \%$ by 1995 , and has since stabilized at $60-70 \%$. There has been active searching for seamount habitat, and by 2000 about $80 \%$ of known seamounts in the appropriate depth range had been fished. In New Zealand there are widespread concerns that seamount habitat needs to be managed carefully. In May 2001, 19 seamounts were given some protection through a ban on bottom trawling.
\end{abstract}

Heavy bottom trawl gear is known to have a direct physical effect on the seabed. Seamounts are often small in size, and trawling can rapidly become concentrated in a very localized area. Seamount habitat is thought to be productive, but may also be fragile, and there is growing concern about the effects of fishing on biodiversity and ecosystem productivity. In this paper we report on ongoing research to examine the extent of impact on seamount habitat. Detailed fisheries data were analysed to determine the numbers and distribution of individual trawls on seamounts to measure how intensive trawling has been. Photographic surveys of the seafloor and mapping the distribution of benthic fauna have also been carried out to quantify the area of seamounts impacted by trawl gear. Comparisons have been made between heavily-fished and unfished seamounts.

Key words: Conservation, deepwater fisheries, fishing importance, New Zealand, orange roughy, seamounts, trawling impacts

\section{Introduction}

Seamounts are prominent and widely distributed features of the New Zealand marine environment. New Zealand straddles the tectonic plate boundary between the Australian and Pacific plates. Subduction occurs in the northern part of the Exclusive Economic Zone, and consequently active volcanic seamounts are found along the Kermadec Ridge. Intraplate, oceanic plateau, and hot-spot volcanism, as well as tectonic ridge uplifting, rifting of margin volcanoes and continental blocks have formed seamount features over widespread areas (Wright, MS 1999).

Seamounts are widely recognized as areas of high productivity, and the focus of important commercial fisheries based on fish species that form large aggregations in association with them. Pelagic armourhead (Pseudopentaceros wheeleri), redfish (various species of Sebastes), alfonsino (Beryx splendens), pink maomao (Caprodon longimanus), orange roughy (Hoplostethus atlanticus) and oreosomatids (e.g. Pseudocyttus maculatus) are commonly found around seamounts (e.g. Sasaki, 1986; Boehlert and Sasaki, 1988; Rogers 1994; Koslow, 1997; Clark 1999). The major New Zealand fisheries, which occur on seamounts, are fisheries for orange roughy (Hoplostethus atlanticus), oreos (black oreo Allocyttus niger, and smooth oreo Pseudocyttus maculatus), cardinalfish (Epigonus telescopus), alfonsino (Beryx splendens), bluenose (Hyperoglyphe antarctica), and rubyfish (Plagiogeneion rubiginosus). The total catch of these amounts to about 40000 45000 tons each year (Annala et al., MS 2000), which by New Zealand standards is quite substantial, and they are valuable fisheries (export value around US\$ 40 million). 
However, although productive, seamounts are generally regarded as fragile habitat (Uchida et al., 1986; Keating et al., 1987; Rogers, 1994; Probert, 1999). Very little is known about the ecology of seamounts in the New Zealand region, or about the effects that human activities have on their physical and biological integrity. The environmental impact of fishing, especially bottom trawling, is the subject of growing public and political awareness. The effects of trawl gear have long been known - effects like the scraping and ploughing of the sea-bed, sediment resuspension and its smothering impact, destruction of non-target benthic animals, especially non-mobile forms like corals and sponges, and the dumping of processing wastes (see Jones, 1992; Dayton et al., 1995). Along with a dramatic increase in the intensity of fishing in the $20^{\text {th }}$ century, there has been an expanding scientific literature with growing evidence of the actual, not just inferred, impacts, and interest in what this can mean to the habitat and longer term sustainability of the environment (e.g. de Groot, 1984; Hutchings, 1990; Collie et al., 1997; Gislason et al., 2000; Hall, 1999; Koslow et al., 2001)

However, one of the major difficulties researchers face in trying to describe and quantify the impacts of trawling, is determining what the habitat was really like before fishing. Koslow et al. (2001) described marked differences in faunal composition and distribution on fished and unfished seamounts off Tasmania and concluded that, although the depths of the seamounts differed, trawling was responsible for stripping coral cover from the fished features. In New Zealand waters a large number of seamounts have been fished, but there are still areas where similar fished and unfished seamounts are close together. One such area is a group of small seamounts on the northern Chatham Rise, commonly known as the Northwest Hills, or "Graveyard" hills. This region has been heavily fished over the last 10 years, but effort has focussed on a small number of features, giving us the potential to examine seamounts in very close geographic proximity, of a broadly similar size, depth range and elevation, that have been fished to varying degrees.

In this paper we describe the importance of seamounts to some of the deepwater fisheries in New Zealand, some results from on-going work assessing the impacts of trawl fisheries, and what is being done to protect the environment.

\section{Methods}

\section{Determining catch from seamounts}

Individual trawl tow information, with location and estimated catch for each trawl, have been recorded by most New Zealand deepwater commercial fishing vessels in the orange roughy and oreo fisheries since the early-1980s. Catch and effort data are held in a database by the New Zealand Ministry of Fisheries, from which we extracted all tows, which targeted and/ or caught orange roughy, oreos (black, smooth, and unspecified), black cardinalfish, alfonsino, bluenose, and rubyfish. Orange roughy and oreo data extend back to the $1970 \mathrm{~s}$, but for the other species most of the fishing effort has occurred since 1989, and this earlier data (collected under a slightly different system) was not examined. For all fisheries, some data are recorded on forms that do not have detailed positional data. The amount of catch from these is believed generally to be minor in the total fishery (in general less than $10 \%$ of the catch and effort), and these were excluded from the analysis.

The start positions of tows were compared to the centre positions of known seamounts, which were determined from bathymetry and research surveys. The term "seamounts" has in recent years been applied to a wide range of undersea mountain or hill features (Rogers, 1994) and in this paper we use the definition of a discrete hill-like feature with a vertical elevation of $100 \mathrm{~m}$ or more above the seafloor (after Brodie and Clark, in press). There are about 800 of these features in the general New Zealand region, with a concentration in northern waters and along the axis lines or flanks of major ridges and rises. Within the New Zealand EEZ, they cover about $3 \%$ of the surface area.

To test whether the observed distribution of catch and effort in relation to seamounts was non-random, a set of 1000 random tow positions was generated within the overall area and the distances from the random positions to the nearest seamount were calculated. A total of 100 sets of 1000 random positions were generated, and these were used to determine the $5 \%$ and $95 \%$ bounds for a random distribution.

\section{Development of a fishing importance index}

In order to quantify the importance of a seamount for deepwater fisheries, we have summarized 
information on effort, catch, and consistency in a single index.

The fishing importance index $(F I I)$ for an individual seamount is defined as follows:

$$
F I I=\sum_{i=1}^{n} E_{i} C_{i} y_{i}
$$

$E_{i} \quad$ is the number of tows targeted at species $i$ within $10 \mathrm{~km}$ of the seamount centre

$C_{i}$ is the catch in tonnes (target or non-target) of species $i$ within $10 \mathrm{~km}$ of the seamount centre

$y_{i} \quad$ is the number of years in which there were 10 or more tows targeting species $i$ within $10 \mathrm{~km}$ of the seamount centre,

$\sum^{n}$ is a summation across all $n$ species which are $\sum_{i=1}$ targeted on seamounts

A distance of $10 \mathrm{~km}$ was chosen to an extent arbitrarily, although this was felt to encompass the likely distance of a vessel away from a seamount during a trawl. Tow duration on a seamount is generally less than 30 minutes, during which time the vessel travelling at about 3 knots has covered 2-3 $\mathrm{km}$. The distance of the net behind the vessel varies with depth, but typically is around 2-3 km. Most fished seamounts are relatively small, with a radius of $2-5 \mathrm{~km}$. Therefore, allowing for some target fishing towards the base of the seamount, the vessel position when the net lands on the bottom should be $8 \mathrm{~km}$ or less. We added some extra distance to allow for the positional rounding as fishers record the tow location to the nearest minute of a degree. Note that when a tow started less than $10 \mathrm{~km}$ from more than one seamount, the catch and effort from that tow was assigned to the nearest seamount only. This introduces some errors where seamounts are close together, and while fishing one seamount, the vessel position is closer to a neighbouring seamount. However, this is only a minor problem, as most seamounts are at least $5 \mathrm{~km}$ apart, which enables the tow start position to be assigned to the correct feature.

This fishing index incorporates data about catch, effort, consistency (the number of years the seamount been fished), and diversity of target species in quantifying the importance of a seamount. By definition a seamount is most important if it sustains high levels of catch and effort over a large number of years in a variety of different fisheries.

We calculated the fishing importance index by target species for orange roughy, oreo (smooth, black and non-specific combined), cardinalfish, alfonsino, bluenose, and rubyfish. The total fishing importance index is equal to the sum of the individual species FIIs.

\section{Seamount surveys}

The study areas. The Graveyard hills area on the northern Chatham Rise (Fig. 1) has been heavily trawled for orange roughy since the early-1990s. However, the effort has concentrated on 3 or 4 main commercial features. Work by NIWA and The Orange Roughy Management Company Ltd. (an industry quota-owners association) in a fisheries survey in 1999 revealed a number of seamounts nearby that had not been trawled. Two of these (Pyre, Gothic), and one fished seamount (Morgue), have since been closed to bottom trawling. The area therefore presents a number of seamount features in close proximity to one another, with varying levels of trawling intensity. A photographic and epibenthic sled sampling survey was carried out on 8 of these seamounts in April 2001, and although data analysis is continuing, it is appropriate to present a few preliminary findings from the photographic survey of 4 of these, 2 of which have been heavily fished, and 2 lightly (Table 1).

Additional photographic data from a survey on Ritchie Seamount (Fig. 1) in 1999 were included to examine the effects of trawl direction on faunal distribution.

Photographic methods. The Graveyard seamount survey comprised photographic transects carried out in a starburst pattern (north-south, east-west, northeast-southwest, northwest-southeast) centred on the peak of each seamount. Video and digital still cameras, together with acoustic fisheries equipment, were mounted in a frame, and towed slowly along each transect at a height of 3-4 $\mathrm{m}$ above the bottom. Video pictures were taken continuously, although stopped remotely while turning between transects. The digital camera was activated remotely also. Frame position was monitored continuously using the CREST acoustic system (Coombs, MS 1994). This also enabled acoustic data on the seafloor to be obtained. Transects covered a depth range between the top of the seamounts (748$987 \mathrm{~m}$ ) to depths of 1 $000-1100 \mathrm{~m}$ on the flanks. On Ritchie Seamount, transects were run east-west across the seamount.

The position of the camera stations was calculated from the vessel position to give the general direction, and then adjusted to the known depth along that line 


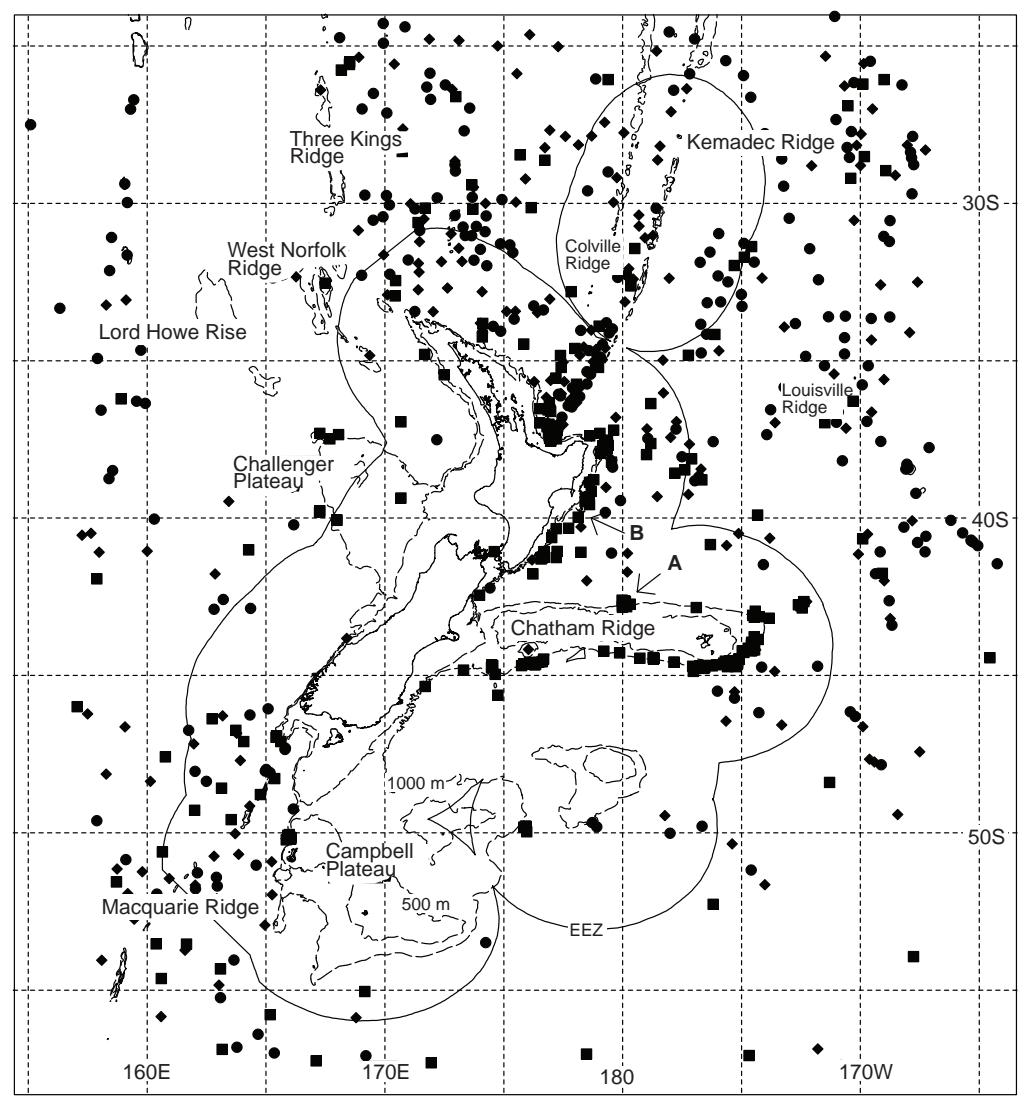

Fig. 1. The New Zealand region, showing major bathymetric features, the sites of photographic surveys carried out on seamounts (A) Graveyard hill complex; (B) Ritchie Hill), and the distribution of seamounts. Key to elevation symbols: circle $=\geq 1000 \mathrm{~m}$, diamond $=500-1000 \mathrm{~m}$, square $=100-500 \mathrm{~m}$

TABLE 1. Summary of data on depth at the peak, elevation above the seafloor (Elev.), area, and number of tows carried out on four seamounts on the northern Chatham Rise for orange roughy (estimated from commercial catch and research data with individual trawl deployment information).

\begin{tabular}{lcccr}
\hline \hline Seamount & Peak $(\mathrm{m})$ & Elev $(\mathrm{m})$ & Area $\left(\mathrm{km}^{2}\right)$ & No. tows \\
\hline Graveyard & 748 & 352 & 4.1 & 1300 \\
Morgue & 890 & 310 & 3.1 & 600 \\
Diabolical & 894 & 156 & 1.0 & 10 \\
Gothic & 987 & 173 & 2.0 & 4 \\
\hline
\end{tabular}

from detailed bathymetry. All still photographs were assessed for percent cover by coral, and the presence or absence of trawl gear marks (nets, wire, trawl door or ground gear furrows).
A series of trawl shots with a small epibenthic sled (dimensions approx. $1 \mathrm{~m}$ wide by $1.5 \mathrm{~m}$ long) were carried out in various parts of the seamount. Samples from this work are still being examined, and 
will be reported in a more comprehensive analysis of survey results (both photographic and sled) in future (Rowden et al., MS 2002; Clark et al., in prep).

\section{Results}

\section{Seamount distribution}

In the general New Zealand region there are about 800 seamounts, defined for this paper as discrete mountain-like features with a vertical elevation of 100 $\mathrm{m}$ or more (Fig. 1). This plot shows 3 categories determined by the elevation of the seamount above the seafloor at its base:

- greater than $1000 \mathrm{~m}$, the classic oceanographic definition of a seamount, of which most in New Zealand waters are offshore.

- between $500 \mathrm{~m}$ and $1000 \mathrm{~m}$, termed knolls

- features between $100 \mathrm{~m}$ and $500 \mathrm{~m}$ elevation, often called pinnacles. There are about 400 of these, mostly near the coast.

These seamounts vary in size, from less than 1 $\mathrm{km}^{2}$ to over $35000 \mathrm{~km}^{2}$. Most are smaller than 100 $\mathrm{km}^{2}$ in area (Fig. 2). They cover a range in depth at their peak from less than $50 \mathrm{~m}$ from the surface, to over $5000 \mathrm{~m}$, and their average slope varies from 2 degrees to over 50 degrees (Brodie and Clark, in press.). However, all tend to represent a similar habitat, in terms of being hard and rocky "islands" sitting above the typically soft sediment of the New Zealand shelf and slope.
Quantifying the importance of seamounts for each fishery

Plots were constructed showing the cumulative distribution of targeted effort and catch (target and bycatch) as a function of distance from the nearest seamount for each fishery (Fig. 3). Only data from 1988-89 to 1999-2000 were included, where positional data are regarded as accurate with the introduction of GPS. These plots reflect the relative importance of seamounts in each fishery (summarized in Table 2). In the cardinalfish fishery, for example, most of the targeted effort (78\%) and catch $(76 \%)$ is taken within $10 \mathrm{~km}$ of a seamount centre. Fifty percent of the cardinalfish effort and catch occurs within 4 $\mathrm{km}$ of a nearby seamount, and $90 \%$ occurs within $27-$ $28 \mathrm{~km}$ of seamounts. Fisheries for rubyfish are less focused on seamount features, with only $24 \%$ of targeted effort and $15 \%$ of catch occurring within 10 $\mathrm{km}$ of a seamount, and half the catch and effort occurs within $20 \mathrm{~km}$ of a seamount. The proportion of the catch taken from seamounts for oreos tends to be higher than the proportion of effort, because oreos are taken as a by-catch in the orange roughy fishery, which is more heavily targeted at seamount features.

From the summary information in Table 2, it is possible to rank the fisheries according to their dependence on seamounts. The cardinalfish fishery is most dependent on seamounts followed by orange roughy and oreo fisheries. Alfonsino, bluenose, and rubyfish fisheries are less dependent on seamounts with a higher proportion of the catch and effort

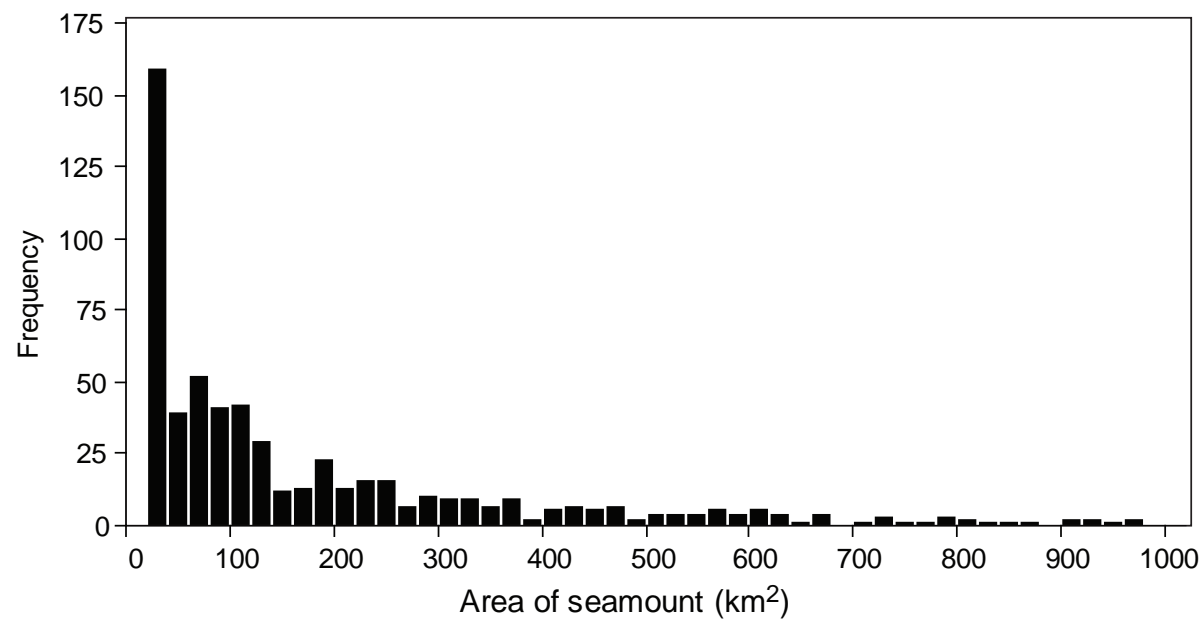

Fig. 2. Size frequency distribution of New Zealand seamounts. Seamount area is grouped into $20 \mathrm{~km}^{2}$ bins, and the frequency represents the number of seamounts of that area-bin (several seamounts with areas in excess of $1000 \mathrm{~km}^{2}$ are not plotted). 

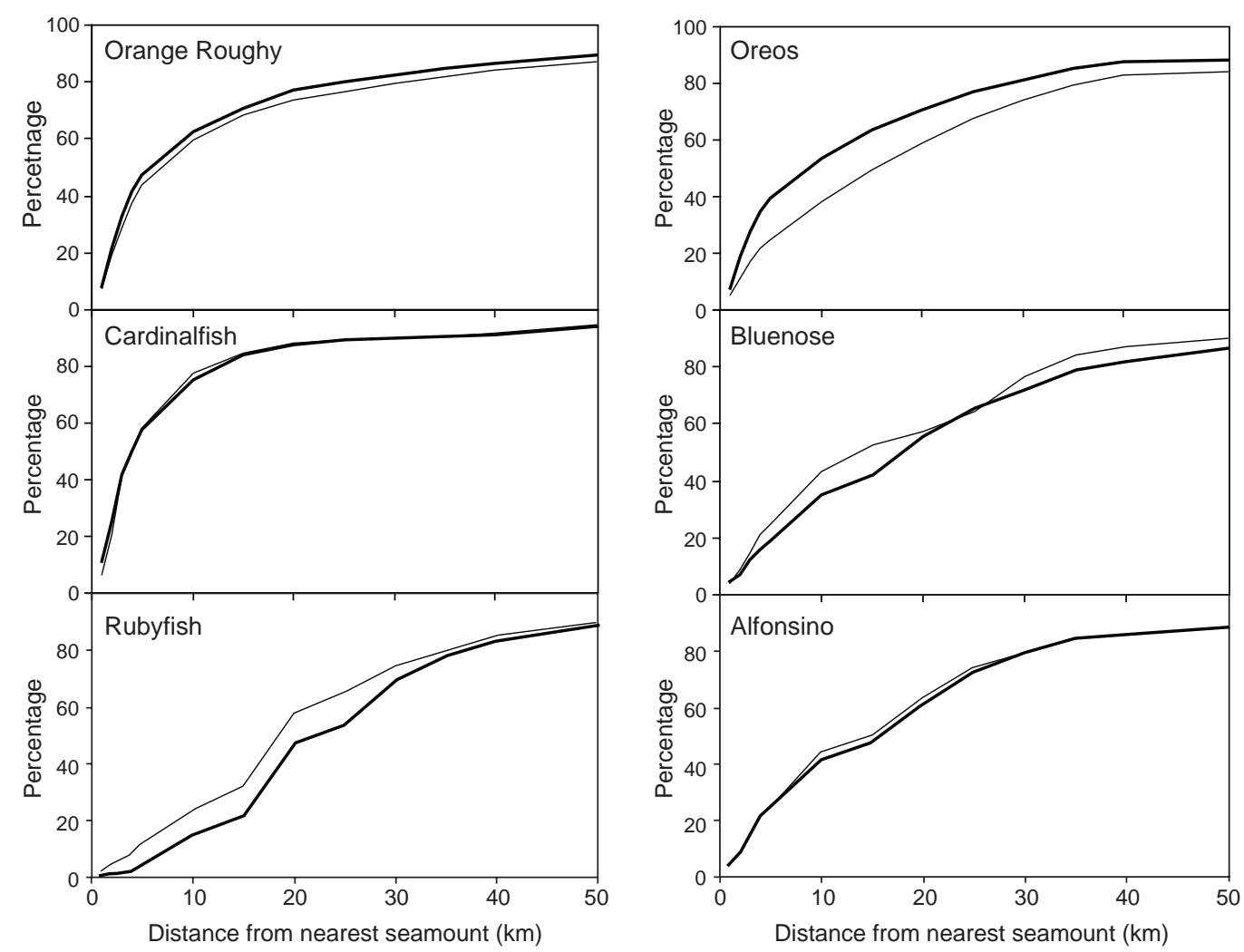

Fig. 3. Cumulative distribution of targeted effort (thin lines), and catch (thick lines) from both target and non-target tows, in relation to distance from the nearest seamount. Test statistics, such as the percentage of tows within $10 \mathrm{~km}$, and the distances from seamounts where $50 \%$ or $90 \%$ of the catch is taken (Table 2) may be read off these plots.

occurring away from seamount features. However, all fisheries were much more closely associated with seamounts than might be expected if the catch and effort was distributed randomly.

\section{Changes in importance of seamounts over time}

The percentages of targeted effort and catch within $10 \mathrm{~km}$ of a seamount centre were plotted as a function of fishing year, from 1979-80 to 1999-2000 for orange roughy and oreos, and from 1988-89 to 1999-2000 for cardinalfish, alfonsino, bluenose, and rubyfish (Fig. 4). The threshold of $10 \mathrm{~km}$ was deemed as likely to be targeted at the seamount, given the 2 $\mathrm{km}$ level of precision in positional reporting. Exploratory analysis suggested that the results were not particularly sensitive to the choice of threshold over the range $5-50 \mathrm{~km}$.

There has been a general increasing trend in the proportion of orange roughy fishing effort and catch from seamounts. From 1980-81 to 1983-84 less than $30 \%$ of tows targeted at orange roughy were within $10 \mathrm{~km}$ of a seamount. This proportion increased to a peak of $70 \%$ in 1994-95, and has since declined to about $60 \%$. Fisheries for oreos and rubyfish also appear to show an increasing trend in the importance of seamounts, but sample sizes were variable. There is little evidence of trends for the other fisheries. Seamounts have been very important $(>60 \%$ of targeted tows) in the cardinalfish fishery since the start of the data series in 1988-89.

The number of seamounts exploited by the deepwater fisheries has increased dramatically over time (Fig. 5). In 1978-79 only one of the seamounts in the database had more than 10 tows within $10 \mathrm{~km}$ of their centre positions. By 1999-2000, 248 seamounts had been fished with more than 10 tows (Table 3). Since 1993-94 more than 100 individual seamounts have been fished each year. The rapid increase in the number of exploited seamounts occurred mainly in the early-1990s when more than 20 new seamounts were fished each year. This "discovery phase" was probably related to several factors including declining catches on some established seamount fisheries, an improved 
TABLE 2. Distribution of catch and effort in relation to known seamounts from trawl logbook data 1988-89 to 1999-2000. The oreos fishery includes tows targeting or catching black, smooth, and unspecified oreos. "Random" are the results expected when tow positions were generated at random. Ranges in parentheses are the $95 \%$ confidence intervals from repeated randomizations. "Distance $(\mathrm{km})$ from nearest seamount centre of 50\%" signifies the distance within which $50 \%$ of the total catch was taken over the time period studied, and similarly for " of $90 \% "$.

\begin{tabular}{|c|c|c|}
\hline & \multicolumn{2}{|c|}{ Percentage within $10 \mathrm{~km}$ of known seamount centres } \\
\hline & Targeted effort & Total catch \\
\hline Cardinalfish & 77.5 & 75.5 \\
\hline Orange roughy & 59.5 & 62.4 \\
\hline Oreos & 38.3 & 53.3 \\
\hline Alfonsino & 43.8 & 41.3 \\
\hline Bluenose & 43.4 & 34.9 \\
\hline Rubyfish & 23.5 & 14.9 \\
\hline \multirow[t]{3}{*}{ Random } & $1.7(1.1-2.4)$ & $1.7(1.1-2.4)$ \\
\hline & \multicolumn{2}{|c|}{ Distance $(\mathrm{km})$ from nearest seamount centre of $50 \%$} \\
\hline & Targeted effort & Total catch \\
\hline Cardinalfish & 4.0 & 4.0 \\
\hline Orange roughy & 6.6 & 5.7 \\
\hline Oreos & 15.4 & 8.7 \\
\hline Alfonsino & 15.1 & 15.8 \\
\hline Bluenose & 12.7 & 19.2 \\
\hline Rubyfish & 19.1 & 22.3 \\
\hline \multirow[t]{3}{*}{ Random } & $91.4(85.5-95.3)$ & $91.4 \quad(85.5-95.3)$ \\
\hline & \multicolumn{2}{|c|}{ Distance $(\mathrm{km})$ from nearest seamount centre of $90 \%$} \\
\hline & Targeted effort & Total catch \\
\hline Cardinalfish & 28.4 & 27.1 \\
\hline Orange roughy & 59.7 & 52.9 \\
\hline Oreos & 151.4 & 70.7 \\
\hline Alfonsino & 59.3 & 54.9 \\
\hline Bluenose & 48.6 & 59.1 \\
\hline Rubyfish & 52.3 & 52.3 \\
\hline Random & $241.8(223.2-257.6)$ & $241.8(223.2-257.6)$ \\
\hline
\end{tabular}

technology (e.g. GPS allowing very accurate navigation, more advanced trawl-monitoring equipment) and improved bathymetric information (including a number of large swathe-mapping surveys), which allowed fishers to locate new features. In the last few years of the 1990s there is evidence for a levelling off, with fewer new seamounts being discovered, and the number of seamounts being fished annually stabilizing.

Most of this fishing of seamounts is driven by the orange roughy fishery (Table 3 ). Of the 248 seamounts that have had more than 10 tows, 217 were fished for orange roughy. Most have a depth at the peak of between $500 \mathrm{~m}$ and $1000 \mathrm{~m}$, and of the total number known within that depth range, almost $80 \%$ are now fished (Fig. 6).

\section{Fishing importance index}

The number of trawls that have been carried out on individual seamounts is shown in Fig. 7. Although several seamounts have had thousands of tows on them, most have had less than 500. This may not appear to be high intensity fishing compared to some other fisheries, but given the small size of many of the seamounts it represents very intense effort.

The fishing importance index results are summarised in Fig. 8. This includes the top 10 seamounts for orange roughy and oreo fisheries, and 

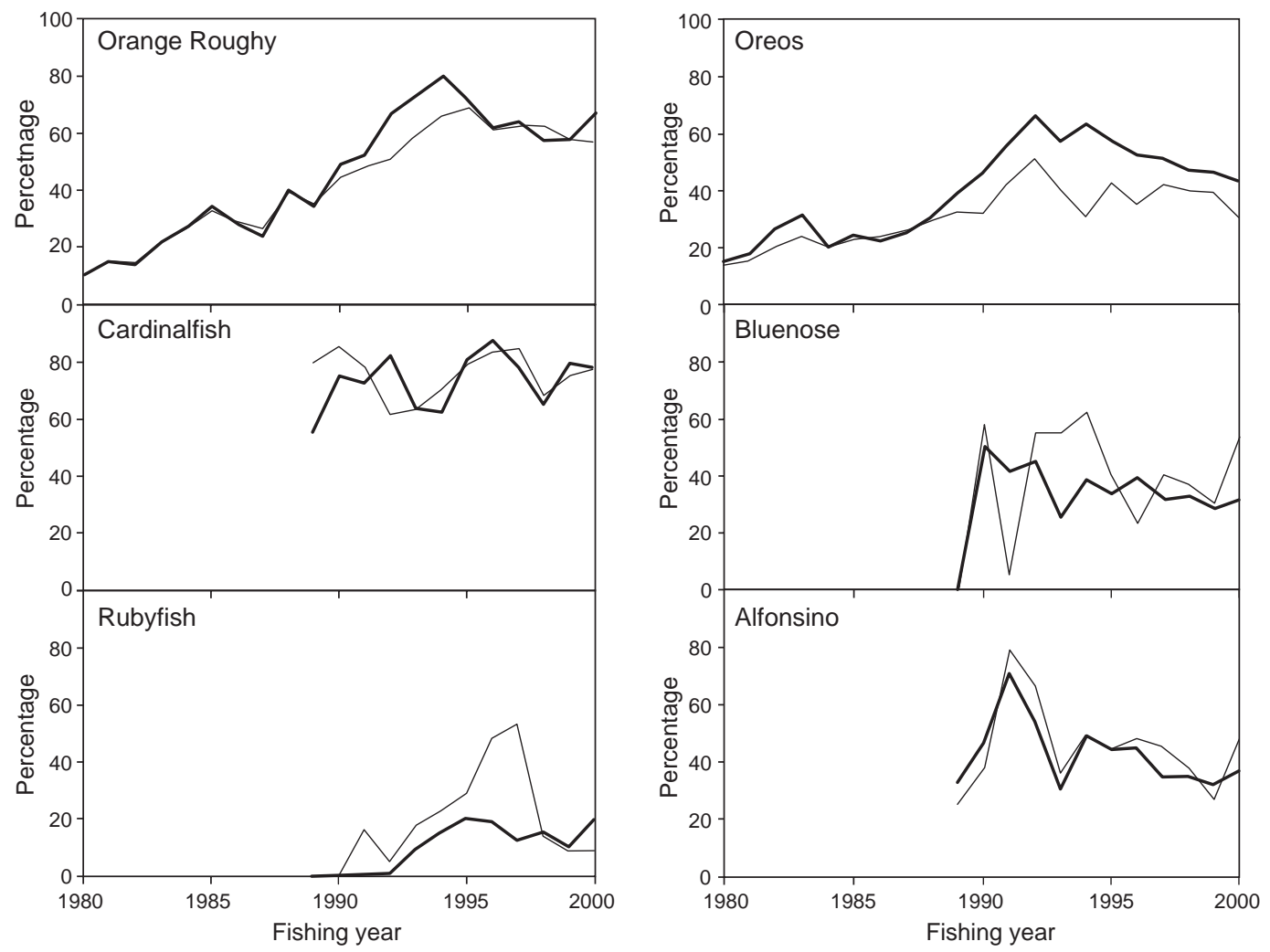

Fig. 4. Annual changes in the percentage of targeted effort (thin lines), and catch (thick lines) from both target and non-target tows, within $10 \mathrm{~km}$ of a seamount centre. Data prior to 1988-89 were not examined for cardinalfish, alfonsino, bluenose or rubyfish.

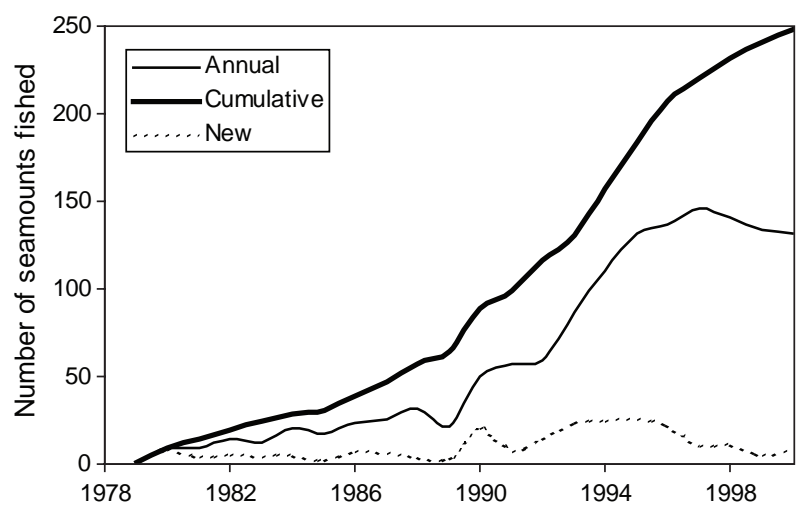

Fig. 5. Changes in the number of exploited seamounts over time. The "annual" total is the number of seamounts fished in that given fishing year. The "cumulative" total is the total of all seamounts, which have accumulated more than 10 tows since the start of the fishery. The "new" total is the number of previously unexploited seamounts, which are fished in any given year.

the top three for cardinalfish, alfonsino, and bluenose (for which only a small number of seamounts were important). Rubyfish was not plotted, as it is more a
TABLE 3. Cumulative total of exploited seamounts up until the end of the 1999-2000 fishing year. The oreos fishery includes tows targeting black, smooth, and unspecified oreos.

\begin{tabular}{lc}
\hline \hline & $\begin{array}{c}\text { Number of seamounts } \\
>10 \text { tows }\end{array}$ \\
\hline Orange roughy & 217 \\
Oreo & 81 \\
Cardinalfish & 25 \\
Alfonsino & 22 \\
Bluenose & 4 \\
Rubyfish & 5 \\
All deepwater & 248 \\
\hline
\end{tabular}

slope fishery. Some key data and results from these main seamounts are summarized in Table 4 . This gives a better indication of the importance of individual seamounts to the various fisheries, and also the relative contribution by the various factors in the FII. Typically, a seamount is important for only one or two species. There is a strong linkage between alfonsino and bluenose, and to a lesser extent 


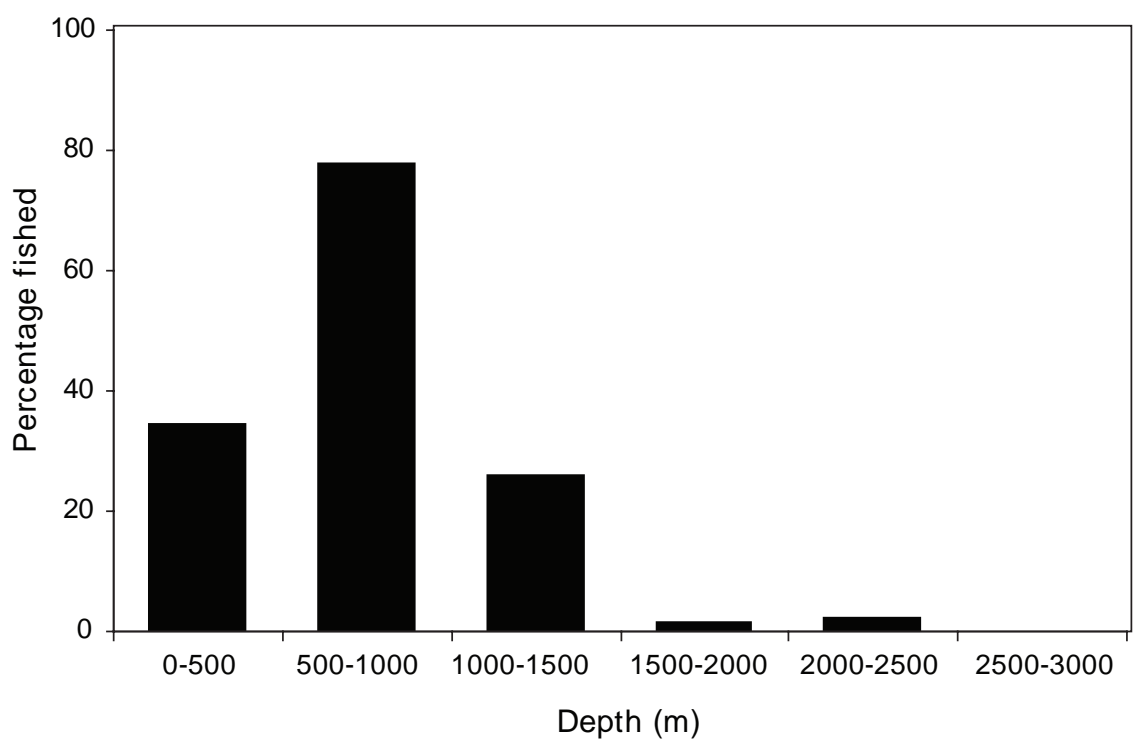

Fig. 6. Depth distribution of exploited seamounts expressed as a percentage of all known seamounts.

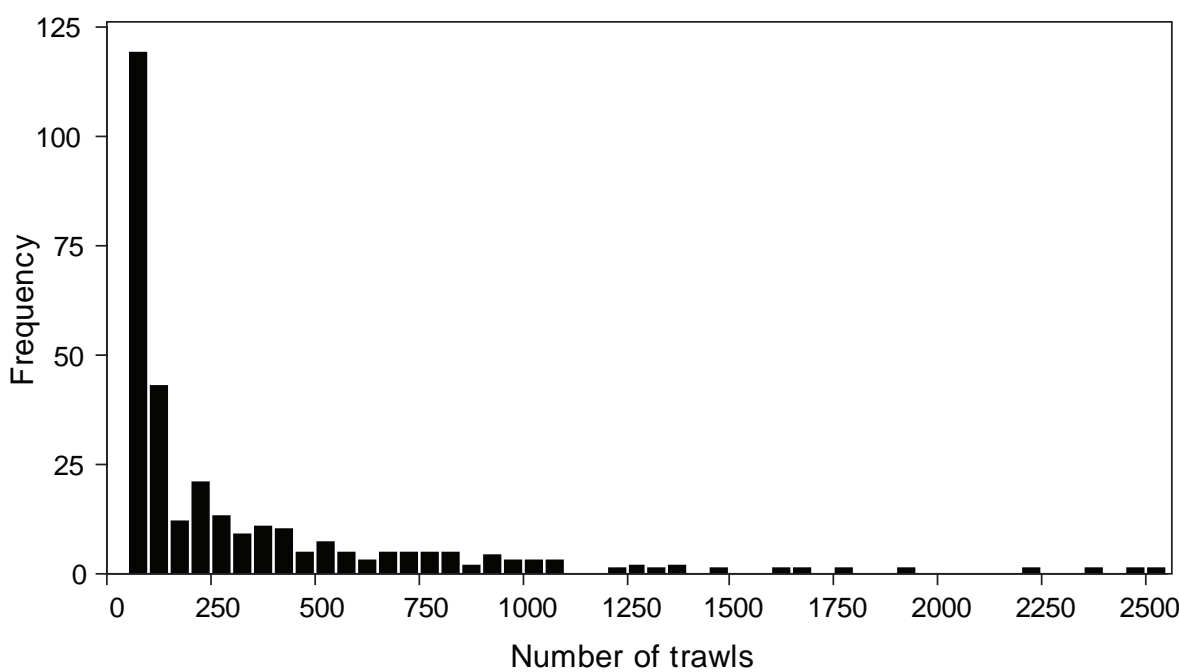

Fig. 7. Trawl frequency on seamounts showing number of trawls grouped into bins of 50 . The frequency represents the number of seamounts that have had the number of trawls carried out on them. The axis label at 250 represents 200-250 bin. Three seamounts with more than 2500 tows (up to 4500 ) are not graphed.

cardinalfish. Although oreos are frequently caught as by-catch in the orange roughy fishery, the principal seamounts are different.

The most important seamounts for orange roughy occurred on the Chatham Rise (e.g. Mt Kiso, Smiths City, Possum, Big Chief, Crack), which has sustained a large orange roughy fishery for 20 years. Other seamounts of importance in this fishery were on the Challenger Plateau (Megabrick, Twin), and off the east coast of the North Island (Ritchie, Main Hill near East Cape), and a single feature (Goomzy) on the Puysegur Bank south of the South Island. The main oreo seamounts occurred on the Chatham Rise, especially along the southern flanks (Trevs Pinnie, Mt Kiso, Fletchers, Neils Pinnie) and several other small 


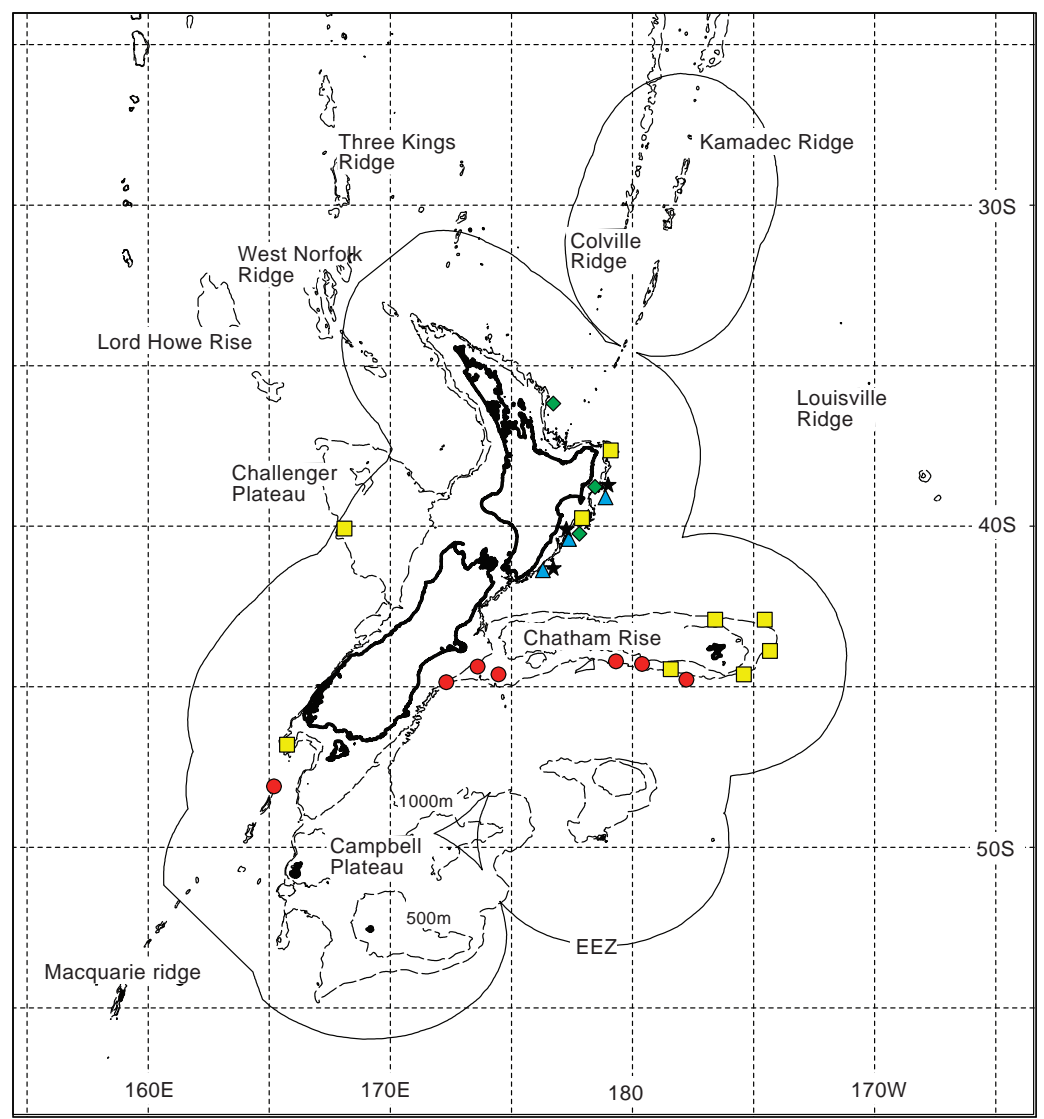

Fig. 8. Distribution of the most important seamounts in fisheries for orange roughy (yellow squares), oreos (red circles), black cardinalfish (green diamonds), alfonsino (black stars) and bluenose (blue triangles). Symbols on the same seamount have been offset for clarity.

features on the southwest Chatham Rise. Seamounts east of the North Island were major areas of fishing for alfonsino and bluenose, and the three most important were the same for both species. Black cardinalfish was also taken from seamounts off the east coast (\#280 and Tolaga Knoll) and off the Colville Ridge (Colville Knolls).

\section{Fishing intensity and direction}

Another element of fishing pressure on the habitat is the direction of tow, that can determine how much of the seamount area is affected. On some seamounts there is almost a shot-gun type coverage, whereas on others the direction of the trawl is dictated by where the bottom is foul or very steep, and so on some there appears to be a natural "trawl corridor". Examples of the shot-gun type coverage are "Smiths City" (northeastern Chatham Rise) and "Mt Whales"
(Louisville Ridge), where tow directions are relatively evenly spread, with the maximum frequency of around $25 \%$ between north and northeast (Fig. 9). In contrast, Mercury Knoll (Bay of Plenty) and Ritchie seamount have a high proportion of tows in a single direction, with around $60 \%$ of all tows on Mercury Knoll having been north-northeast, south-southwest on Ritchie. On this latter seamount, the top is heavily marked with gouges from the trawl doors and bobbins (Fig. 10) and there is very little macro-fauna present. The plot shows the position of camera stations running across the seamount where such marks were observed. The main impact is on the peak and upper slopes, primarily along a north-south axis, with few marks on the flanks. This matches the reported trawl tow line data well, considering that fishers record to the nearest minute of a degree, and some of the offset trawls are due to such rounding of the vessel's position. It appears about $50 \%$ of the seamount area has been impacted. 


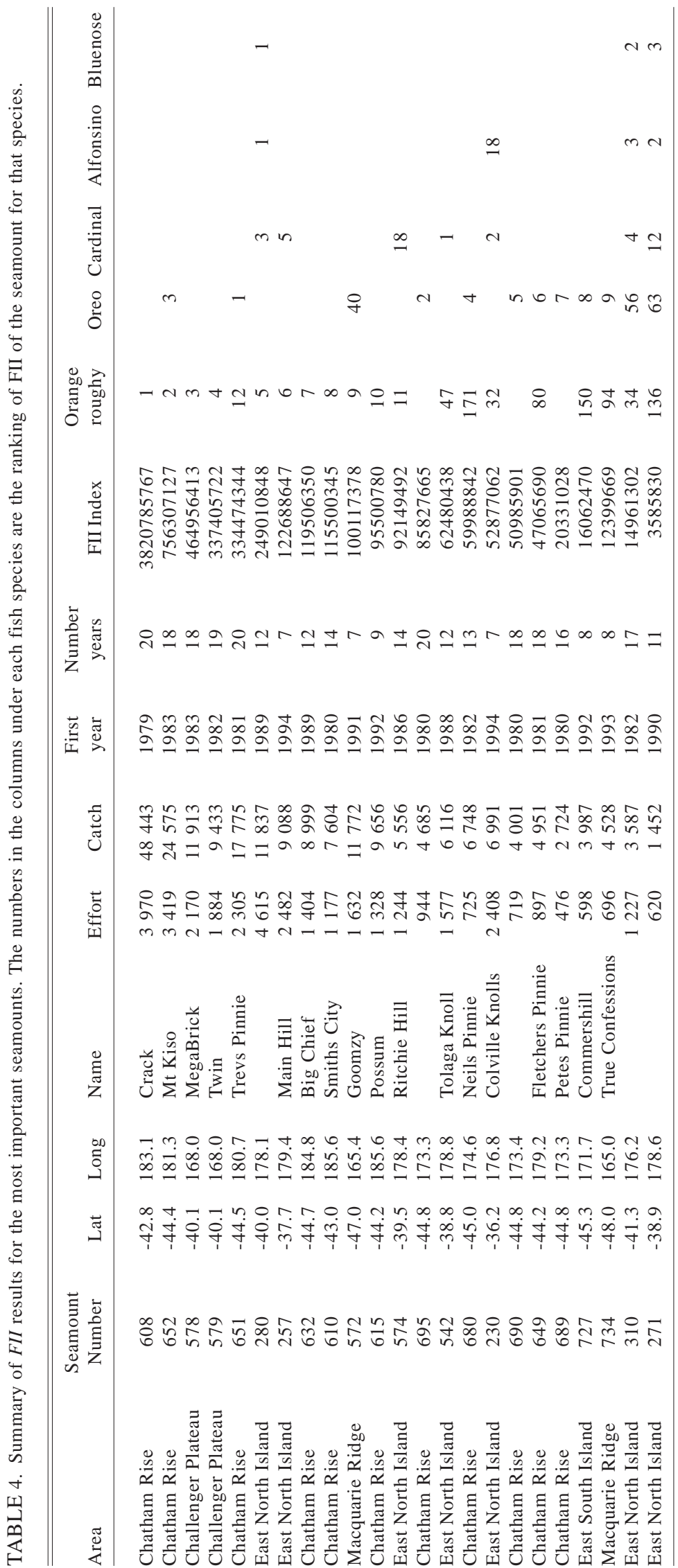




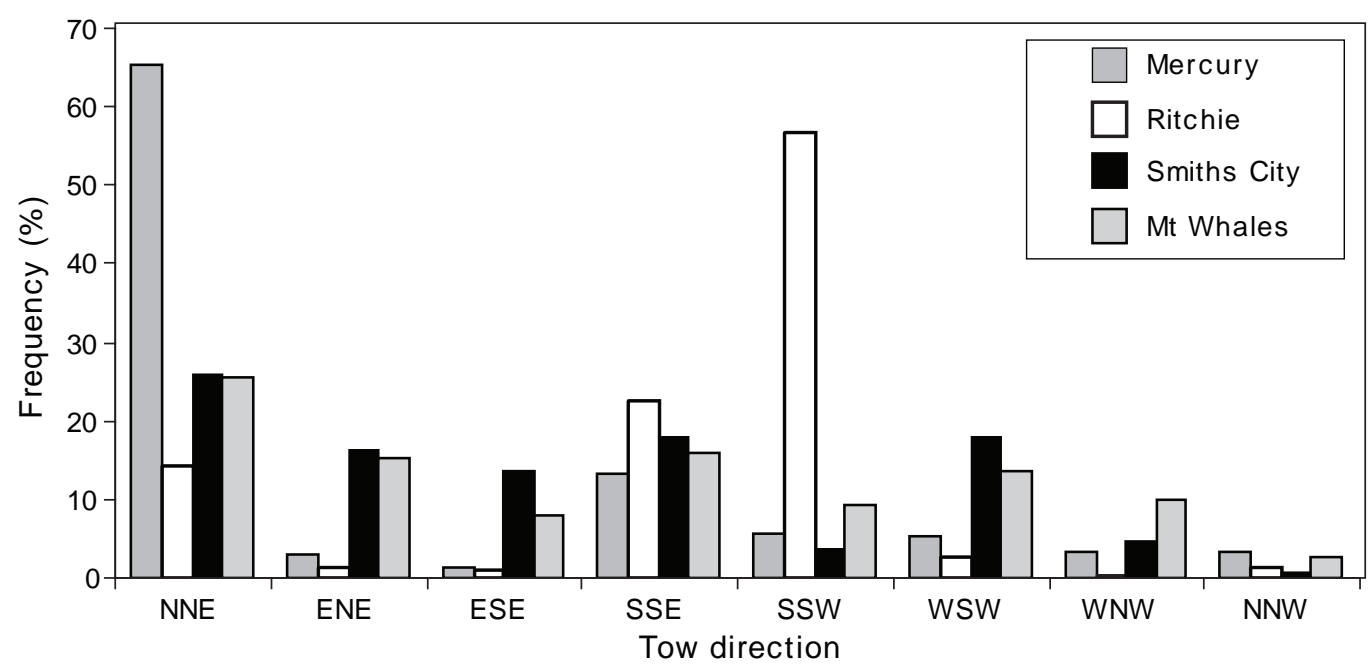

Fig. 9. Frequency distribution of the direction of trawls for orange roughy (grouped into $45^{\circ}$ bins) on four seamounts.

\section{Chatham Rise seamount survey}

Graveyard and Morgue were characterised by large areas of barren seafloor, where there was exposed basement rock, coral fragments or soft sediment. Few live invertebrates were seen. However, on the less fished Diabolical and Gothic, some dense coral patches and much more invertebrate life were observed. Faunal data are still being analysed (Rowden et al., MS 2002), but the distribution of erect coral (mostly live scleractinian species Solenosmilia variabilis and Madrepora oculata) shows a very strong contrast between the fished and unfished seamounts (Fig. 11). Small and isolated occurrences of coral on Graveyard and Morgue were never more than $2-3 \%$ of the photograph area, while on Diabolical and Gothic $100 \%$ cover was often recorded. The expanding symbol plot in Figure 11 shows the concentrations of coral were on the tops of both Diabolical and Gothic, extending over a depth interval of $50 \mathrm{~m}$ down the eastern flanks of Diabolical, and were distributed more generally on the flanks of Gothic.

Evidence of damage from trawl gear (pieces of wire, netting, in particular gouges from trawl doors or bobbins) also differed between the seamounts (Fig. 12). Evidence of damage was widespread on Graveyard, where $29 \%$ of all photographs showed some impact. Morgue also had a relatively high level $(17 \%)$ of photographs with signs of bottom impact, although the distribution was more concentrated on the eastern upper flanks, and down the northwestern slope. Diabolical and Gothic were less impacted, with signs of trawl gear impact in $5 \%$ and $1 \%$ of photographs respectively.

Data on the catch composition of fish trawls carried out on these 4 seamounts during research surveys were also examined (Table 5). The fish catch from the "fished" seamounts (Graveyard and Morgue) was high, but the catch of bottom living invertebrates was very small. By contrast, the catch contained large quantities of coral in the "unfished" Diabolical and Gothic.

\section{Seamount protection}

Maintenance of biodiversity and productive ecosystems are key goals of several New Zealand government departments. These offshore seamounts and their fisheries lie within the jurisdiction of the Ministry of Fisheries, and in 2000 the Minister of Fisheries signalled his intention to close several seamounts to bottom trawling and dredging. This protection was formalized in May 2001, when 19 seamounts were protected under a Seamounts Management Strategy (Anon., 2001).

These protected seamounts are spread throughout the New Zealand region (Fig. 13). They are partitioned into 4 biogeographic zones (from Clark et al., MS 2000), and vary in their size and depth (Table 6). Although little was known about their fauna, it was hoped this would protect representative faunas from 


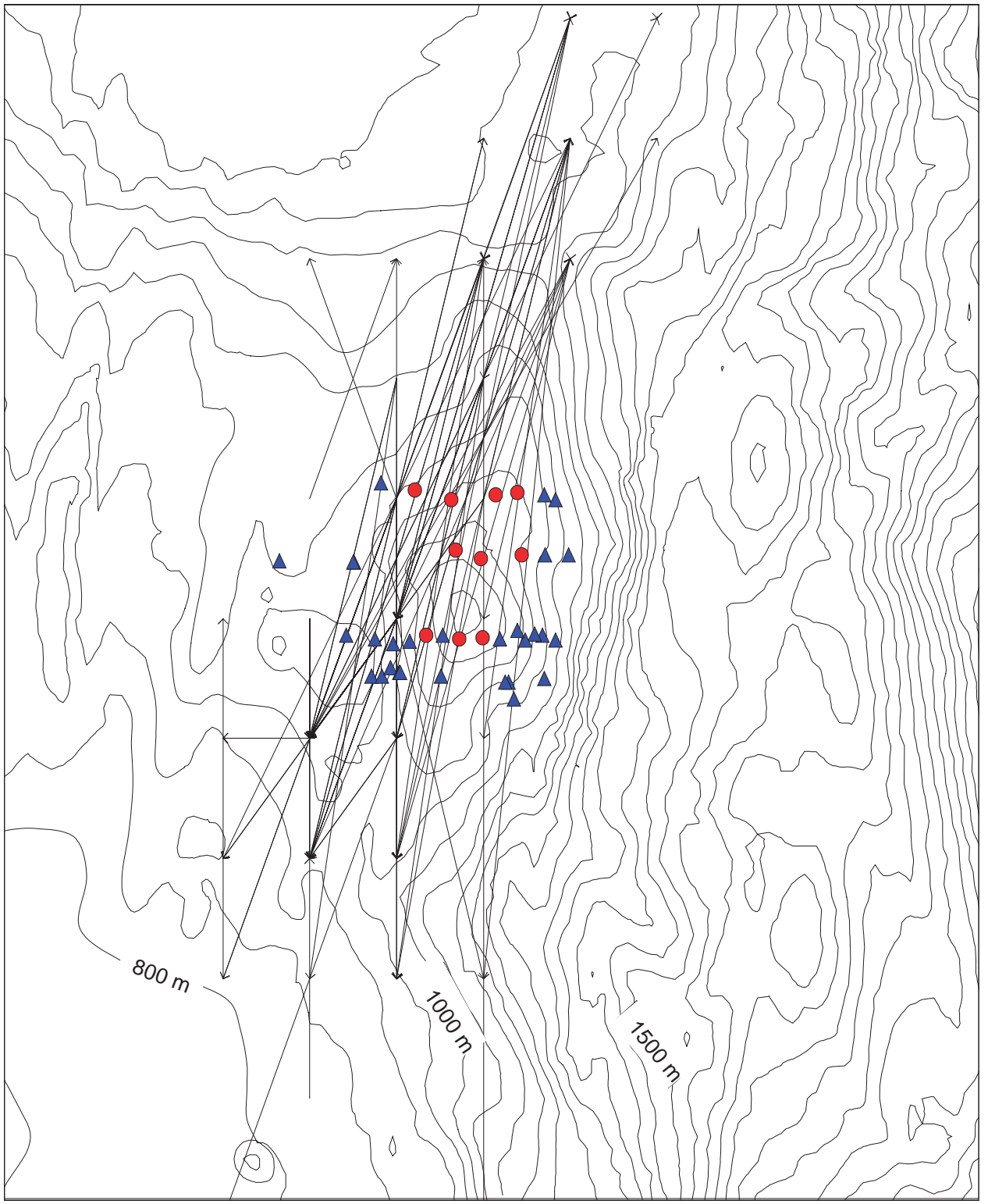

Fig. 10. The Ritchie seamount. The positions of camera stations carried out on east-west transects by NIWA in 1999 are shown (red circles = signs in the photograph of trawl gouges, blue triangles show no disturbance). Commercial trawl lines are plotted for the period 1996 to 1999 (Ministry of Fisheries data). Depth contours are in $50 \mathrm{~m}$ intervals.

a variety of habitat types. They are all unfished except for Morgue, which was intentionally included to monitor to see what recolonization and regeneration might occur over time, once fishing is removed.

\section{Discussion}

Seamounts are important habitats for deepwater fish species in New Zealand. Orange roughy, black cardinalfish, and oreo (especially smooth oreo) fisheries are based primarily on seamounts. Although it was known from an early stage in the development of these fisheries that aggregations formed over seamounts, the increase in their importance in the fisheries came about through a combination of improved technology allowing them to be located and fished more accurately and safely, as well as the decline in catch levels or quotas on some of the more 

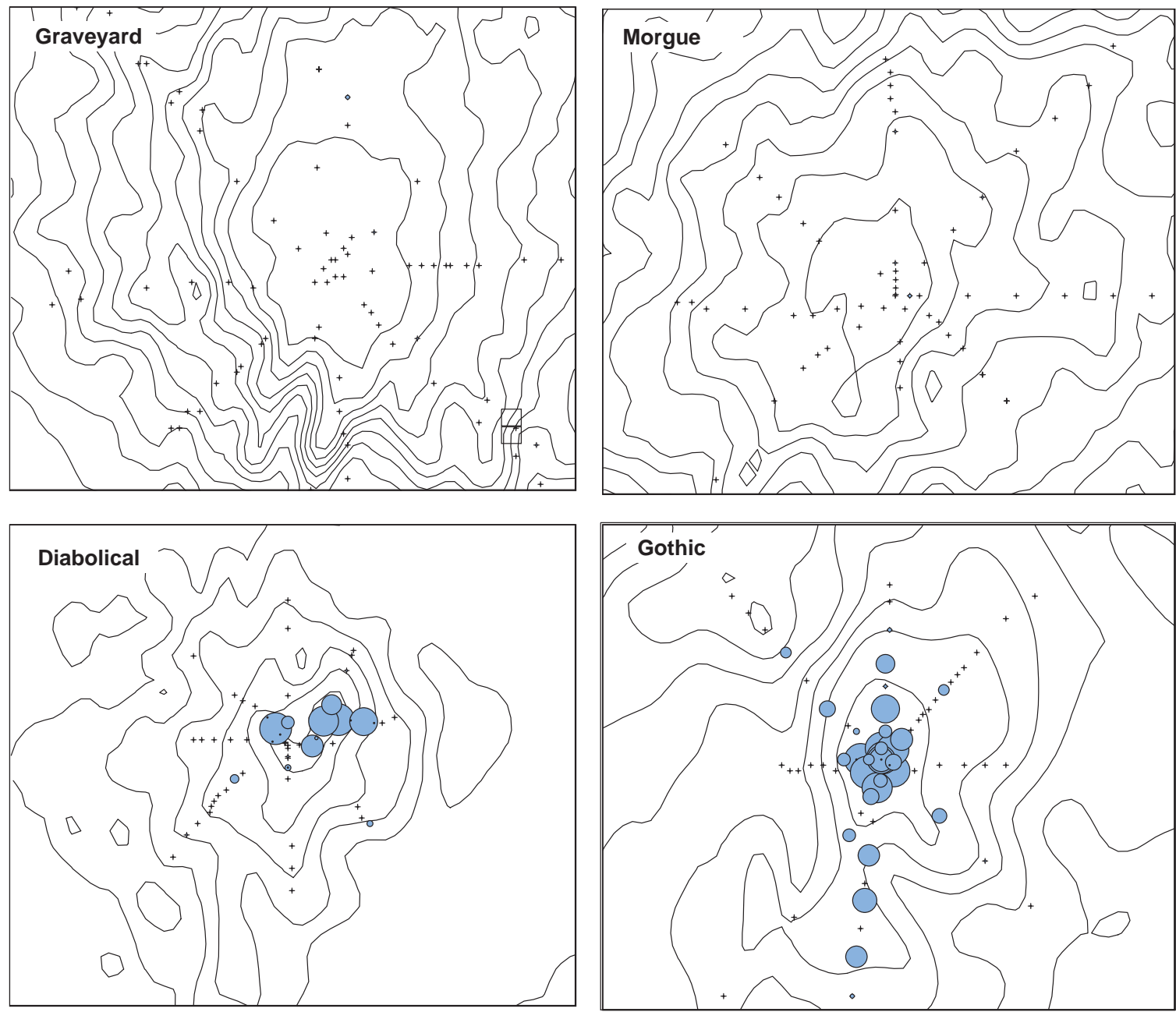

Fig. 11. The distribution of erect coral on the four surveyed seamounts on the northern Chatham Rise. Small crosses represent the location of each camera station. The expanding symbols indicate the relative amount of seafloor in the photograph covered by coral (circle size proportional to coral cover, maximum $=100 \%$ ).

established fisheries on flat slope. The figures presented here differ slightly from the estimates made by Clark (1999), as the location of more seamounts, and a more rigorous analysis of trawl-seamount location, have improved their quality.

The Fishing Importance Index presented here is a combination of a number of factors accounting for abundance of a fish species (catch), the time period over which the fishery has taken place (duration), and the amount of effort in the fishery (number of trawls). Because of limitations on the accuracy of the reported position of commercial tows (to the nearest minute of a degree), care needs to be exercised to attempt to avoid inclusion of trawls close to a seamount, but on an adjacent bottom (which is relatively flat and distinct from the slope of the flanks of the seamount).
The high FII for the "Crack" seamount may partly be due to this, as there is a large fishery on flat bottom close to this feature. Trawls on seamounts are often relatively short (in both distance and duration), and this could be a means of more accurately separating seamount tows in future analyses.

Seamounts are readily identifiable bathymetric features, and so provide a focal point for both the fish, and the fishery. Aggregations of orange roughy can be rapidly overfished (Koslow et al., 1997; Clark, 2001), and serial depletion of stocks can occur in which a seamount is located, fished heavily, and then left as catches decline and the fishery moves onto new seamounts (Clark, 1999; Clark et al., 2000). Although individual seamount catch levels can be applied to limit the amount of catch (as done under some 

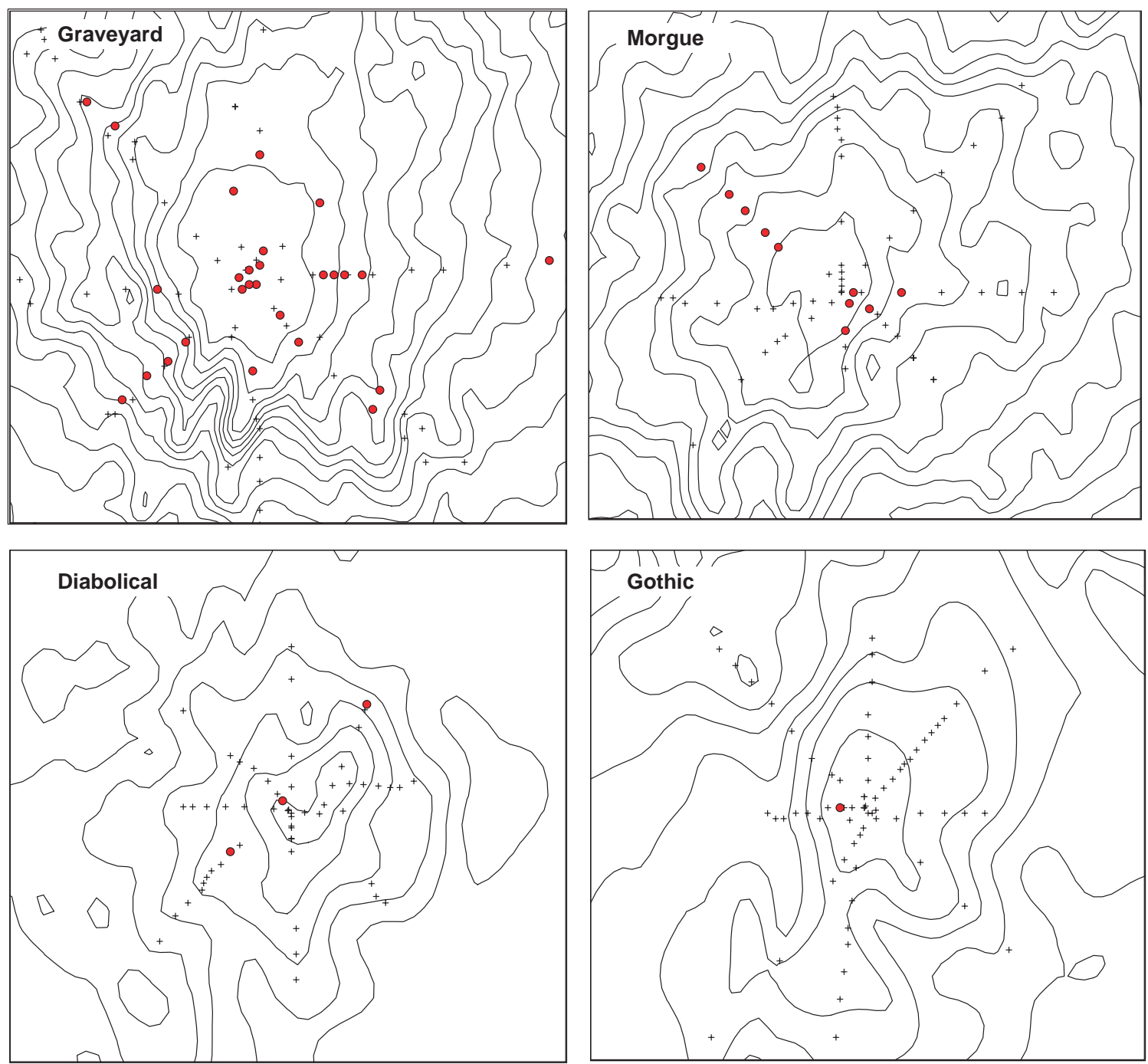

Fig. 12. Distribution of evidence of trawl gear impact on the seafloor of the four surveyed seamounts on the northern Chatham Rise. Small crosses represent the location of each camera station. The closed circle indicates trawl impact at that station.

exploratory fishing programs in New Zealand), impacts on the benthos can still occur depending on the number and direction of trawling operations. Closure of a number of relatively unfished seamounts, however, is a way of protecting biodiversity of the benthic fauna without having a large effect on commercial fisheries. For many of the closed seamounts, very little was known about their faunal composition, and so to some extent the protection of their biodiversity was a stab in the dark. However, surveys on three of these (Gothic, Rumble III, Brothers) have revealed a host of species (probably at least 30 ) that are either new to the New Zealand region or completely undescribed (Rowden et al., MS 2002). A large number of new species were also found in surveys of seamounts off southern Tasmania (Koslow et al. 2001).

It is often difficult to get good comparative data on the benthic fauna from fished and unfished seamounts, because the rapid rate of fisheries development can see all seamounts in a productive area fished in a very short time. An example of this was the development of an orange roughy fishery on a cluster of seamounts off East Cape. It began with heavy fishing on one seamount, but rapidly extended within 2 years to a further 11 adjacent features (Clark et al., MS 1999). This rapid development can see many suitable deepwater features exploited well in advance of scientific research. This has occurred in 
TABLE 5. Catch composition summary of trawls carried out on 2 fished seamounts (Graveyard, Morgue), and 2 unfished seamounts (Diabolical, Gothic), Northern Chatham Rise.

\begin{tabular}{lrr}
\hline \hline & Fished & Unfished \\
\hline No. trawls & 13 & 6 \\
Total catch (kg) & 18500 & 21650 \\
Coral (kg) & 5 & 3000 \\
\% coral (by weight) & $<0.01$ & 14 \\
\hline
\end{tabular}

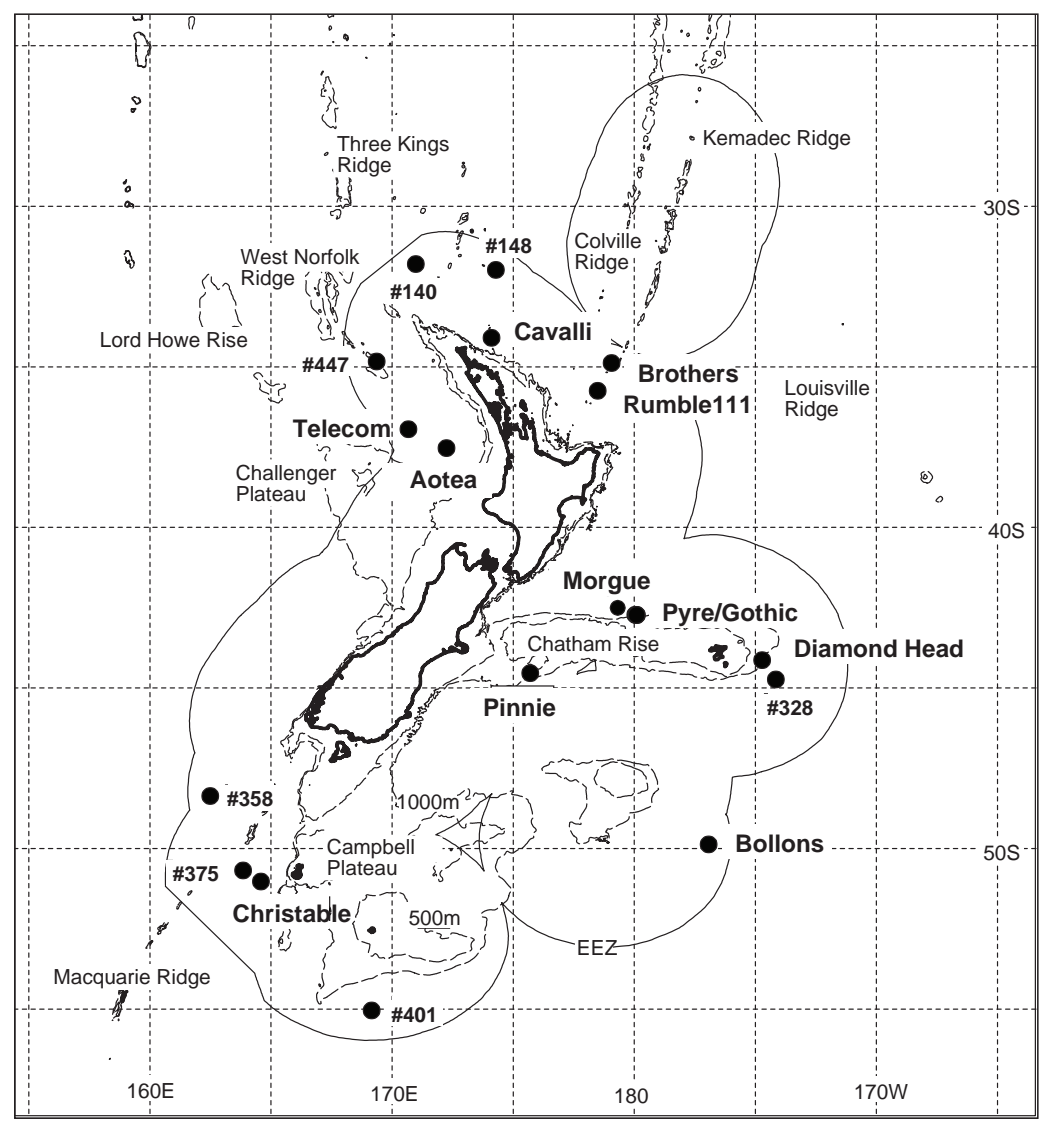

Fig. 13. The New Zealand region, showing the location of protected seamounts (closed to trawling in 2001).

some of the major orange roughy fisheries in both New Zealand (e.g. Chatham Rise; Clark, 2001) and Australia (e.g. southern Tasmania; Koslow et al., 2001).

Evidence of trawl gear impact is often indirect. In the bottom photographs, we regularly observed extensive patches of broken and fragmented coral. These occurred on both the fished and unfished seamounts. Video footage showed coral fragments scattered widely when impacted by the camera frame, and such a lack of linear pattern of coral debris would make the cause of fragmentation hard to determine. It is possible that damage to coral outcrops occurs naturally as well as by the physical disruption of trawling. Because of this, we used only clear evidence of trawl disturbance on the bottom, which in most cases were gouges and furrows in the sediment 
TABLE 6. Summary information on depth of the peak, elevation (from the base to peak), area, and biogeographical region of protected seamounts (from Clark et al., MS 2000).

\begin{tabular}{lrrrl}
\hline \hline Name & Depth & Elevation & Area $\left(\mathrm{km}^{2}\right)$ & Region \\
\hline \#148 & 677 & 2600 & 190 & Northern North Island \\
Cavalli & 538 & 1050 & 125 & Northern North Island \\
\#140 & 1750 & 2900 & 590 & Northern North Island \\
Brothers & 197 & 1300 & 35 & Northeast North Island \\
Rumble III & 200 & 3200 & 300 & Northeast North Island \\
Aotea & 900 & 1200 & 500 & Western North Island \\
Telecom & 1500 & 250 & 20 & Western North Island \\
\#447 & 615 & 650 & 120 & Western North Island \\
Pinnie & 600 & 200 & 5 & Southern Chatham Rise \\
Morgue & 890 & 310 & 3 & Northern Chatham Rise \\
Pyre & 1004 & 200 & 1 & Northern Chatham Rise \\
Gothic & 987 & 170 & 2 & Northern Chatham Rise \\
Diamond Head & 603 & 500 & 3 & Eastern Chatham Rise \\
\#328 & 1750 & 1200 & 600 & Eastern Chatham Rise \\
\#358 & 1652 & 2400 & 2000 & Southwest South Island \\
Bollons & 800 & 3600 & 35000 & Southeast New Zealand \\
\#375 & 684 & 570 & 460 & Southern South Island \\
Christable & 910 & 2400 & 2170 & Southern South Island \\
\#401 & 1159 & 340 & 200 & Southern New Zealand \\
\hline
\end{tabular}

attributable to doors and bobbins (and not natural geological fractures). On the hard rocky surfaces where the sessile fauna attaches, trawl gear often doesn't leave an impression, but all these seamounts have a mix of hard areas and patches of softer and shallow overlying sediment. Marks were clearest in the softer sediment, and there was little doubt from the parallel nature of many of them, and the rounded "furrow" pattern, that fishing gear was the cause.

The growing concern around the world about the effects of fishing, and also mining, was one of the reasons for carrying out the present research. Knowledge and hard data on the amount of effort being applied to seamounts, and the value of the habitat to the commercial fishery, are important considerations in evaluating management measures to provide protection for the environment, yet enable exploitation where it is sustainable. There is clear evidence of a substantial impact on the benthic fauna from deepwater trawl fisheries in New Zealand, and the need for active management to conserve these environments. This ongoing research can hopefully contribute to adopting measures to preserve biodiversity and perhaps the underlying productivity of the ecosystem, in time.

\section{Acknowledgements}

This work was supported by research funding from the Foundation for Research Science and Technology (contract no. CO1X0028), and Ministry of Fisheries (contract code ZBD2000/04). We are grateful to Ken Downing for development of the still camera system, and to Andy Hill and Alan Hart for examining many of the still photographs. Sam McClatchie (NIWA), Kent Gilkinson and Jon Moore made constructive and useful improvements to the manuscript.

\section{References}

ANNALA, J. H., K. J. SULLIVAN, and C. J. O'BRIEN. MS 2000. Report from the Fishery Assessment Plenary, May 2000: stock assessments and yield estimates. 495 p. (Unpubl. report held in NIWA library, Wellington.)

ANON. 2001. Seamount closures. Seafood New Zealand, June 2001, 21 p.

BOEHLERT, G. W., and T. SASAKI. 1988. Pelagic biogeography of the armorhead, Pseudopentaceros wheeleri, and recruitment to isolated seamounts in the North Pacific Ocean. Fish. Bull., 86: 453-465.

BRODIE, S., and M. R. CLARK. (in press). The New Zealand Seamount Management Strategy - steps towards conserving offshore marine habitat. In: Proceedings of 
the World Congress on Aquatic Habitat Protected Areas, Cairns, August, 2002, pp. 664-673.

CLARK, M. R. 1999. Fisheries for orange roughy (Hoplostethus atlanticus) on seamounts in New Zealand. Oceanol. Acta 22: 593-602.

2001. Are deepwater fisheries sustainable? The example of orange roughy, (Hoplostethus atlanticus) in New Zealand. Fish. Res., 51: 123-135.

CLARK, M. R., O. F. ANDERSON, R. I. C. C. FRANCIS, and D. M. TRACEY. 2000: The effects of commercial exploitation on orange roughy (Hoplostethus atlanticus) of the continental slope of the Chatham Rise, New Zealand, from 1979 to 1996. Fish. Res., 45: 217-238.

CLARK, M. R., S. O'SHEA, D. M. TRACEY, and B. GLASBY. MS 1999: New Zealand region seamounts: aspects of their biology, ecology and fisheries. $107 \mathrm{p}$. (unpublished NIWA Client Report WLG99/32 -available NIWA, P O Box 14901, Wellington).

CLARK, M. R., S. O'SHEA, B. WOOD, and I. WRIGHT. MS 2000: Seamount management: a report on seamounts potentially suitable for consideration under the MFish seamount management strategy. Report prepared for New Zealand Ministry of Fisheries, WLG 00-33, 79 p.

CLARK, M. R., A. ROWDEN, and S. O'SHEA. (In prep). The impacts of deepwater trawling on seamounts of the Chatham Rise, New Zealand.

COLLIE, J. S., G. A. ESCANERO, and P. C. VALENTINE. 1997. Effects of bottom fishing on the benthic megafauna of Georges Bank. Mar. Ecol. Prog. Ser., 155: 159-172.

COOMBS, R. F. MS 1994. An adaptable acoustic data acquisition system for fish stock assessment. International Conference on Underwater Acoustics, 5-7 December 1994, University of New South Wales, Sydney, Australian Acoustical Society.

DAYTON, P. K., S. F. THRUSH, M. T. AGARDY, and R. J. HOFMAN. 1995. Viewpoint: environmental effects of marine fishing. Aquat. Cons.: Mar. Freshwater Ecosystems, 5: 205-232.

De GROOT, S. J. 1984. The impact of bottom trawling on benthic fauna of the North Sea. Ocean Management, 9: 177-190.

GISLASON, H., M. SINCLAIR, K. SAINSBURY, and R. O'BOYLE. 2000. Symposium overview: incorporating ecosystem objectives within fisheries management. ICES J. Mar. Sci., 57: 468-475.

HALL, S. J. 1999. The effects of fishing on marine ecosystems and communities. Fish biology and aquatic resources series 1. Blackwell Science, U.K., 270 p.

HUTCHINGS, P. 1990. Review of the effects of trawling on macrobenthic epifaunal communities. Australian J. Mar. Freshwater Res., 41: 111-120.

JONES, J. B. 1992. Environmental impact of trawling on the seabed: a review. N. Z. J. Mar. Freshwater Res., 26: 59-67.

KEATING, B. H., P. FRYER, R. BATIZA, and G. W. BOEHLERT. (ed.) 1987. Seamounts, islands, and atolls. Geo. Mono., 43: 405 p.

KOSLOW, J. A. 1997. Seamounts and the ecology of deepsea fisheries. Amer. Sci., 85: 168-176.

KOSLOW, J. A., N. J. BAX, C. M. BULMAN, R. J. KLOSER, A. D. M. SMITH, and A. WILLIAMS 1997. Managing the fishdown of the Australian orange roughy resource. In: Developing and sustaining world fisheries resources: the state of science and management. D. A. Hancock, D. C. Smith, A. Grant, and J. P. Beumer (eds.). CSIRO Australia, p. 558-562.

KOSLOW, J. A., K. GOWLETT-HOLMES, J. K. LOWRY, T. O'HARA, G. C. B. POORE, and A. WILLIAMS. 2001. Seamount benthic macrofauna off southern Tasmania: community structure and impacts of trawling. Mar. Ecol. Prog. Ser., 213: 111-125.

PROBERT, P. K. 1999. Seamounts, sanctuaries and sustainability: moving towards deep-sea conservation. Aquat. Cons. Mar. Freshwater Ecosystems, 9: 601-605.

ROGERS, A. D. 1994. The biology of seamounts. $A d v$. Mar. Biol., 30: 305-350.

ROWDEN, A. A., S. O'SHEA, and M. R. CLARK. MS 2002. Biodiversity of seamounts on the northern Chatham Rise. (unpublished report-available NIWA, P. O. Box 14901, Wellington).

SASAKI, T. 1986. Development and present status of Japanese trawl fisheries in the vicinity of seamounts. In: Environment and resources of seamounts in the North Pacific. R. N. Uchida, S. Hayasi, and G. W. Boehlert (ed.). NOAA Tech. Rep. NMFS., 43: 21-30.

UCHIDA, R. N., S. HAYASI, and G. W. BOEHLERT. (eds) 1986. Environment and resources of seamounts in the North Pacific. NOAA Tech. Rep., NMFS, 43: 105 p.

WRIGHT, I. C. MS 1999. New Zealand region "seamounts": a preliminary characterisation of their physical setting (unpublished NIWA Client Report WLG99/24 - available NIWA, P. O. Box 14901, Wellington). 